\title{
MODEL BIMBINGAN KELOMPOK SEBAGAI STRATEGI PENDIDIKAN KARAKTER BERBASIS LATIHAN PERMAINAN
}

\author{
Darimis \\ Program Studi Bimbingan Konseling, Jurusan Tarbiyah STAIN Batusangkar \\ Korespondensi: J1.Sudirman No.137 Kubu Rajo, Lima Kaum, Batusangkar, Sumatera Barat \\ E-mail: darimis.uptlbk@gmail.com
}

\begin{abstract}
The reality of students' negative attitude made Indonesia goverment had not moved forward nowadays. Most people judged that educational system should take the responsibility to this condition. Education was assumed laying on students' cognitive rather than affective and conative. Reliazing this phenomena, counceling as a part of education offered group counceling as one strategy of character education based playing games. There were twelve playing games that could be applied to build positive character: the practice writing, body movement, circleling, dyad, triad, creative group, art and handcraft, fantasy, reading, feedback, belief, moral dilemma, and group decision.
\end{abstract}

Kata kunci: bimbingan kelompok, karakter, dan latihan permainan

\section{PENDAHULUAN}

$\mathrm{P}$ endidikan karakter akhir-akhir ini marak dibicarakan di media massa dan menjadi isu utama pendidikan nasional. Berbagai kalangan berbicara tentang pendidikan karakter, baik akademisi, pemerhati pendidikan, praktisi, maupun masyarakat umum. Topik ini menjadi sentral pembicaraan banyak orang disebabkan oleh kemerosotan moral bangsa termasuk pelajar.

Kemerosotan moral pelajar, terlihat bentuk perilaku menabrak etika, moral dan hukum, baik dalam kategori ringan, sedang maupun berat, seperti perilaku mencontek saat ulangan atau ujian, keinginan lulus dengan cara mudah tanpa kerja keras, tawuran antar pelajar, pesta minuman keras, pergaulan bebas, penyalahgunaan narkoba. Bahkan fenomena yang memburukkan citra pelajar adalah maraknya "gang motor", perilaku gang ini sering-kali menjurus pada tindak kekerasan yang meresahkan masyarakat. Semua perilaku negatif pelajar tersebut menunjukkan kerapuhan karakter anak bangsa. (www.puskur buk.net).

Realitas perilaku pelajar tersebut secara tidak langsung mengakibatkan kemunduran bangsa, karena ada hubungan erat antara kualitas karakter dan kemajuan bangsa, sebagaimana yang diungkapkan oleh Thomas Lickona dalam Ratna Megawangi (2004:7) bahwa ada sepuluh tanda-tanda zaman yang harus diwaspadai, jika tanda-tanda itu sudah ada, maka itu berarti bahwa suatu bangsa sedang menuju kehancuran. Tanda-tanda tersebut adalah: (1) meningkatnya kekerasan di kalangan remaja, (2) penggunaan bahasa dan katakata yang memburuk, (3) pengaruh peer 
group yang kuat dalam tindak kekerasan, (4) meningkatnya perilaku merusak diri, seperti penggunaan narkoba, alkohol, dan seks bebas, (5) semakin kaburnya pedoman moral baik dan buruk, (6) menurunnya etos kerja, (7) semakin rendahnya rasa hormat kepada orang tua dan guru, (8) rendahnya rasa tanggung jawab individu dan warga Negara, (9) membudayanya ketidakjujuran, dan (10) adanya rasa saling curiga dan kebencian di antara sesama.

Tanda-tanda zaman yang diungkapkan oleh Lickona di atas sudah terjadi di negara ini, padahal suatu peradaban akan menurun apabila terjadi demoralisasi pada masyarakatnya. Kemudian muncul pertanyaan mendasar, ada apa dengan bangsa ini? dan mengapa ini semua terjadi?. Siapa pun akan berpikir untuk menjawab pertanyaan di atas, namun banyak pihak yang menuding sistem pendidikan yang paling bertanggung jawab terhadap kemerosotan moral anak bangsa. Pendidikan dinilai terlalu menonjolkan kognisi siswa, namun minus afeksi, hal ini pernah disinyalir oleh Masnur (2011: 200) bahwa sistem pendidikan yang ada sekarang ini terlalu berorientasi pada pengembangan otak kiri (kognitif) dan kurang memperhatikan pengembangan otak kanan (afektif, empati, dan rasa). Padahal pengembangan karakter lebih berkaitan dengan optimalisasi fungsi otak kanan. Ada juga yang berpendapat bahwa pendidikan terkesan mekanistis, penuh hafalan, dan menafikan kreatifitas peserta didik, jangankan membenahi karakter mencerdaskan saja belum. Pendidikan terlalu fokus pada "content" kurang memperhatikan "process", tidak berharap kepada "apa" tetapi kepada "siapa". (http://azharaarsyad.uin-alaudin .ac.id/index $/$ php?hal=3 \& model = full = 223)

Berdasarkan fenomena kemerosotan moral peserta didik di atas, maka penulis berpikir bahwa membangun karakter merupakan suatu kemestian di semua tingkat dan satuan pendidikan dengan porsi dan strategi yang relevan dengan usia dan tingkat perkembangan peserta didik. Tulisan ini akan membahas beberapa konsep pendidikan karakter menurut perspektif bimbingan dan konseling dengan fokus utama pengembangan karakter melalui bimbingan kelompok melalui teknik latihan permainan sebagai salah satu teknik bimbingan kelompok untuk meningkatkan kreativitas peserta didik sekaligus sebagai ikhtiar untuk membangun karakter peserta didik.

\section{PEMBAHASAN}

Tulisan ini berisi konten-konten terkait dengan berbagai aspek karakter, baik pengertian karakter, pendidikan karakter, dan karakter dasar yang dapat dikembangkan melalui kegiatan layanan bimbingan kelompok sebagai layanan primadona dalam bimbingan dan konseling. Argumentasi mendasar pemakaian bimbingan kelompok sebagai strategi pendidikan karakter adalah keistimewaan bimbingan kelompok dibandingkan jenis layanan konseling yang lain, dengan satu layanan bimbingan kelompok dapat dikembangkan berbagai aspek diri peserta didik, baik aspek kognitif dengan informasi baru, aspek afektif dengan aneka konten kerjasama dan tenggang rasa, maupun aspek psikomotor dengan berbagai latihan permainan yang dapat mengolah pikir, olah rasa, olah hati, dan olah raga.

Tulisan ini akan memaparkan hal tersebut secara panjang lebar, terutama sekali pemaparan konsep karakter, pendidikan karakter, dan karakter dasar, serta konsep dan aplikasi bimbingan kelompok, karena bagaimanapun pendidikan karakter sebagai fokus bimbingan dan konseling atau dengan kata lain sebagai bagian sentral dari upaya pengembangan diri dengan berbagai 
aspek potensi, bakat, tipikal, atau kepribadian peserta didik.

\section{Pengertian Karakter dan Pendidikan Karakter}

Karakter mengacu pada serangkaian sikap dan perilaku untuk melakukan hal yang terbaik, seperti berperilaku jujur dan bertanggung jawab, mempertahankan prinsip-prinsip moral dalam situasi yang penuh ketidakadilan, kecakapan interpersonal yang memungkinkan seseorang berinteraksi secara efektif dalam berbagai keadaan, dan komitmen untuk berkontribusi dengan kelompok masyarakat. Menurut Battistich dalam Arismantoro (2009: 65) individu yang berkarakter baik adalah seseorang yang berusaha melakukan yang terbaik. Lebih lanjut karakter menurut Alwisol dalam Arismantoro (2009:67) diartikan sebagai gambaran tingkah laku yang menonjolkan nilainilai benar-salah, baik-buruk, baik secara eksplisit maupun implisit.

Pengertian karakter di atas, menurut kajian psikologi maupun konseling menekankan pada aspek tingkah laku yang terikat nilai, apakah nilainya positif maupun negatif, karakter berwujud tingkah laku yang ditunjukkan kepada lingkungan sosial, relatif parmanen serta menuntun, mengarahkan, dan mengorganisasikan aktivitas individu.

Secara etimologi karakter berasal dari bahasa Yunani yaitu "charassein" yang berarti mengukir sehingga terbentuk suatu pola, dalam bahasa Inggris disebut dengan "to mark" (menandai) dan memfokuskan pada aplikasi nilai kebaikan dalam bentuk tindakan atau tingkah laku (Wynne dalam Ratna Megawangi, 2004:3). Jadi, seseorang berperilaku tidak jujur, kejam, atau rakus dikatakan sebagai orang yang berkarakter jelek, sedangkan orang yang berperilaku jujur, suka menolong, dikatakan sebagai orang yang berkarakter mulia. Jadi istilah karakter erat kaitannya dengan kepribadian seseorang.

Selanjutnya pendidikan karakter menurut Abdullah Nasih Ulwan (2004: 136) adalah suatu usaha yang sengaja dilakukan agar objek didik memperoleh sekumpulan prinsip-prinsip budi pekerti, karakter yang mulia dan keutamaankeutamaan perilaku dan perasaan, lalu terbiasa melakukannya sejak dini sampai ia dewasa dan bergumul dengan kehidupan nyata. Lebih tegas lagi menurut Akhmad Sudrajat, pendidikan karakter adalah suatu sistem penanaman nilainilai karakter kepada warga sekolah yang meliputi komponen pengetahuan, kesadaran atau kemauan, dan tindakan untuk melaksanakan nilai-nilai tersebut, baik terhadap Tuhan Yang Maha Esa (YME), diri sendiri, sesama, lingkungan, maupun kebangsaan sehingga menjadi manusia sempurna atau insan kamil. (http://akhmadsudrajat.wordpress.com/2 010/08/20/pendidikan).

Untuk mendukung pendidikan karakter di satuan pendidikan, maka seluruh komponen sekolah harus dilibatkan, baik isi kurikulum, proses pembelajaran, kualitas hubungan sosial, penanganan mata pelajaran, pelaksanaan aktivitas ko-kurikuler, dan etos seluruh personil sekolah. Artinya pengembangan karakter merupakan upaya keseluruhan proses pendidikan yang dialami siswa sebagai pengalaman pembentukan kepribadian melalui memahami dan mengalami sendiri nilai-nilai, keutamaan nilai-nilai baik, atau nilai-nilai ideal.

Pendidikan karakter Lickona dalam Ratna Megawangi (2004: 111) menekankan pentingnya tiga komponen karakter yang baik (component of good character) yaitu moral knowing atau pengetahuan tentang moral, moral feeling atau perasaan tentang moral, dan moral action (perbuatan bermoral). Hal ini diperlukan agar siswa mampu memahami, merasakan dan mengerjakan dan sekaligus nilai-nilai kebaikan. 
Jadi, karakter dikembangkan melalui tahap pengetahuan (knowing), perbuatan (acting), menuju kebiasaan (habit). Hal ini berarti bahwa karakter tidak sebatas pengetahuan tentang kebaikan, karena orang belum mampu bertindak sesuai dengan pengetahuannya itu kalau tidak terlatih untuk melakukan kebaikan tersebut. Karakter tidak sebatas pengetahuan, ia lebih dalam lagi menjangkau ranah emosi dan pembiasaan diri. Dengan demikian, pembiasaan diperlukan tiga komponen karakter di atas, sehingga peserta didik mampu memahami, merasakan, dan mengerjakan nilai-nilai kebaikan.

Pada bidang bimbingan dan konseling, istilah pendidikan karakter pada awalnya digunakan oleh Character Education di Amerika. Menurut American School Counselor Association (1998) tujuan pendidikan karakter adalah assist students in becoming positive and self-directed in their lives and education and in striving toward future goal (membantu siswa agar menjadi lebih positif dan mampu mengarahkan diri dalam pendidikan dan kehidupan, dan dalam berusaha keras dalam pencapaian tujuan masa depannya). Tujuan tersebut dilakukan dengan mengajarkan kepada siswa tentang nilai-nilai dasar kemanusiaan, seperti kejujuran, kabaikan, kedermawanan, keberanian, kebebasan, persamaan, dan rasa hormat atau kemuliaan.

Menurut T.Lickona, E.Schaps dan C.Lewis dalam Arismantoro (2009: 156) pendidikan karakter harus didasarkan pada sebelas prinsip berikut: 1) mempromosikan nilai-nilai dasar etika sebagai basis karakter; 2) mengidentifikasi karakter secara komprehensif supaya mencakup pemikiran, perasaan, dan perilaku; 3) menggunakan pendekatan yang tajam, proaktif, dan efektif untuk membangun karakter; 4) menciptakan komunitas sekolah yang memiliki kepedulian; 5) memberi kesempatan ke- pada siswa untuk menunjukkan perilaku yang baik; 6) memiliki cakupan terhadap kurikulum yang bermakna dan menantang; 7) mengusahakan tumbuhnya motivasi diri pada siswa; 8) memfungsikan seluruh staf sekolah sebagai komunitas moral yang berbagi tanggung jawab untuk pendidikan karakter dan setia pada nilai dasar yang sama; 9) adanya pembagian kepemimpinan moral dan dukungan luas dalam membangun inisiatif pendidikan karakter; 10) memfungsikan keluarga dan anggota masyarakat sebagai mitra dalam usaha membangun karakter, dan 11) mengevaluasi karakter sekolah, fungsi staf sekolah sebagai guru-guru karakter, dan manifestasi karakter positif dalam kehidupan siswa.

\section{Karakter Dasar}

Sejumlah nilai-nilai karakter yang diidentifikasi oleh para ahli yang digunakan sebagai pijakan pendidikan karakter, nilai-nilai karakter tersebut dinamakan karakter dasar. Karakter dasar ini menentukan tujuan, kesamaan persepsi dan mengakomodasi nilai karakter universal. Sesuai dengan ungkapan Ratna Megawangi (2004:95) bahwa karakter dasar adalah nilai-nilai karakter yang perlu ditanamkan kepada anak yaitu nilai-nilai universal yang mana seluruh agama, tradisi, dan budaya pasti menjunjung tinggi nilai-nilai tersebut. Nilai-nilai universal ini dapat menjadi perekat bagi seluruh anggota masyarakat walaupun berbeda latar belakang budaya, suku, dan agama.

Di Indonesia, pendidikan karakter didasarkan pada sembilan karakter dasar (Ratna Megawangi, 2004: 96) yang di dalamnya terkandung nilai-nilai universal. Kesembilan pilar karakter dasar tersebut, yaitu: 1) Cinta Tuhan dan segenap ciptaan-Nya (love Allah, trust reverence, loyalty); 2) Kemandirian dan tanggung jawab (responsibility, excellence, self-reliance, discipline, orderliness); 
3) Kejujuran/amanah, ke-bijaksanaan (trustworthiness, reliability, honesty); 4) Hormat dan santun (respect, courtesy, obedience); 5) Dermawan, suka menolong dan gotong royong (love, compassion, caring, empaty, generousity, moderation,cooperation); 6) Percaya diri, kreatif, dan pekerja keras (confidence, assertiveness, creativity, resourcefulness, courage, determination and enthusiasm); 7) Kepemimpinan dan keadilan (justice, fairness, mercy, leadership); 8) Baik dan rendah hati (kindness, friendliness, humility, modesty); dan 9) Toleransi dan kedamaian dan kesatuan (tolerance, flexibility, peacefulness, unity).

Kesembilan karakter dasar di atas telah sesuai dengan Negara Indonesia yang menempatkan kecintaan kepada Tuhan dan alam semesta sebagai substansi dasar ideologi Pancasila. Di samping itu sembilan karakter dasar tersebut merupakan nilai-nilai fundamental yang dijunjung tinggi oleh bangsa Indonesia.

\section{Bimbingan Kelompok}

Bimbingan kelompok merupakan salah satu jenis layanan bimbingan dan konseling. Bimbingan kelompok adalah layanan urutan keenam dari sepuluh jenis layanan, mulai dari layanan orientasi, layanan informasi, layanan penempatan/penyaluran, layanan penguasaan konten, layanan konseling perorangan, layanan bimbingan kelompok, layanan konseling kelompok, layanan konsultasi, layanan mediasi, dan layanan advokasi. Layanan bimbingan kelompok menurut Prayitno (2004: 12) adalah satu layanan bimbingan konseling yang diberikan pada sekelompok orang/siswa dalam suasana kelompok dengan memanfaatkan dinamika kelompok untuk memperoleh informasi dan pemahaman baru dari topik yang dibahas.
Banyak keuntungan pelaksanaan layanan bimbingan kelompok, menurut Rusmana (2005: 78), di antaranya: 1) bimbingan kelompok lebih efektif dan efisien; 2) bimbingan kelompok dapat memanfaatkan pengaruh-pengaruh seseorang atau beberapa orang individu terhadap anggota lainnya; 3) bimbingan kelompok terjadi saling tukar pengalaman di antara para anggotanya yang dapat berpengaruh terhadap perubahan tingkah laku individu; 4) bimbingan kelompok dapat merupakan awal dari konseling individual, sehingga bimbingan kelompok dapat dimanfaatkan untuk mempersiapkan individu yang akan mendapat layanan konseling; 5) bimbingan kelompok menjadi pelengkap dari teknik konseling individual, dalam arti sebagai layanan tindak lanjut dari konseling individual; 6) bagi kasuskasus tertentu, bimbingan kelompok dapat dipergunakan sebagai subtitusi, yakni dilaksanakan karena kasus tidak dapat ditangani dengan teknik lain; dan 7) dalam bimbingan kelompok terdapat kesempatan untuk menyegarkan watak dan pikiran.

Tahapan kegiatan bimbingan kelompok pada setiap kali pelaksanaan layanan bimbingan kelompok, mulai dari: 1) tahap pembentukan; 2) tahap peralihan; 3) tahap kegiatan; dan 4) tahap pengakhiran. Sifat bimbingan kelompok bervariasi, bisa bersifat informatif, bisa juga bersifat terapeutik. Pelaksanaan bimbingan kelompok dapat dilakukan melalui berbagai teknik seperti diskusi, simulasi, latihan, homeroom program, dan sosiodrama. Salah satu metode atau teknik bimbingan kelompok yang ditujukan pada aktifitasaktifitas yang terstruktur, terencana, dan terukur, baik dalam hal durasi waktu, materi dan konsekuansinya salah satunya adalah tenik latihan, terutama sekali latihan permainan. 


\section{HASIL PEMBAHASAN DAN ANALISIS}

Bagian ini menyajikan pembahasan penggunaan berbagai jenis latihan permainan dalam bimbingan kelompok dengan disertai nilai-nilai pendidikan karakter yang ada pada latihan tersebut. Menurut Jacob dalam Rusmana (2009) sekurang-kurangnya ada 13 jenis latihan yang biasa digunakan dalam bimbingan kelompok untuk pengembangan karakter positif, yakni: 1) menulis (written); 2) gerak (movement); 3) lingkaran (rounds); 4) dyad dan triad; 5) creative props; 6) seni dan kerajinan tangan (art and crafts); 7) fantasi; 8) bacaan umum; 9) umpan balik; 10) kepercayaan; 11) dilemma moral; 12) keputusan kelompok; dan 13) sentuhan (touching).

Tiga belas jenis latihan di atas hanya dua belas jenis latihan yang penulis coba paparkan dalam tulisan ini, latihan ini dapat diaplikasikan dalam bimbingan kelompok untuk meningkatkan kreatifitas sebagai upaya pengembangan fungsi otak kanan tempat bersemayamnya karakter atau kepribadian. Untuk lebih jelasnya dua belas latihan tersebut akan dipaparkan berikut ini.

\section{Latihan Menulis}

Latihan menulis terdiri atas aktivitas tulis-menulis. Anggota dapat menulis daftar, pertanyaan, mengisi esai, menuliskan reaksi mereka, atau menandai dengan tanda cek hal-hal seputar isu atau topik yang dibahas. Misalnya latihan melengkapi kalimat artinya setiap anggota kelompok diminta melengkapi pernyataan tertulis dengan cara mengisi titik-titik yang disediakan. Seperti: Saat saya memasuki kelompok baru, saya merasa ...Saat orang pertama kali bertemu saya, mereka:....Saat saya berada dalam kelompok baru, saya merasa nyaman saat:... Saya paling kesal saat konselor:...Dalam kelompok saya paling takut kalau:...

Latihan menulis ini dapat diberikan pada tahap pembahasan topik dalam bimbingan kelompok. Pendidikan karakter yang terkandung dalam latihan ini adalah dapat menambah gagasan atau ide dan pemikiran yang disajikan dalam kelompok, latihan ini akan memunculkan minat dan menambah energi di antara anggota kelompok, karena mereka ingin tahu tentang respon anggota kelompok yang lain terhadap latihan yang sama.

\section{Gerak}

Latihan gerak ini merupakan latihan yang mensyaratkan anggota kelompok untuk melakukan gerakan fisik. Latihan ini bisa berupa kegiatan berdiri dan menggerakan anggota tubuh sederhana ataupun gerakan yang kompleks atau gerakan sesuai irama lagu dan music. Misalnya latihan bertukar tempat duduk, anggota kelompok mencari kursi yang berbeda untuk diduduki. Nilai karakter yang terkandung dalam latihan ini adalah memberikan kesempatan pada anggota kelompok untuk oleh raga, melakukan peregangan dan gerak badan, memberikan ketertarikan kelompok dan energi yang mereka miliki, memberi anggota kelompok kesempatan untuk lebih mengalami sesuatu dari pada hanya sekadar mendiskusikan, dan dapat memudahkan anggota kelompok untuk mengingat apa saja yang terjadi dalam kelompok, karena menimbulkan kesan secara komprehensif terhadap fungsi-fungsi psikis anggota kelompok.

\section{Lingkaran}

Latihan membuat lingkaran adalah latihan yang dilakukan dengan meminta anggota kelompok untuk membuat lingkaran, kemudian konselor mengajukan beberapa pertanyaan dan anggota kelompok menjawab dengan kata-kata 
'sangat setuju', 'setuju', 'tidak setuju' atau 'sangat tidak setuju'. Pernyataannya adalah sebagai berikut: a) Orang kulit hitam dan orang kulit putih tidak boleh menikah; b) Hubungan diluar pernikahan selalu berbahaya; c) Perceraian berarti sebuah kegagalan; d) Seseorang harus mencintai orang tuanya apapun yang terjadi; e) Menikah merupakan hal yang penting bagi kebahagiaan. Respon dari pertanyaan ini memiliki potensi untuk didiskusikan.

Latihan lingkaran ini mengandung pendidikan karakter yaitu kejujuran, tanggung jawab, cinta kebenaran dan keadilan.

\section{Dyad dan Triad}

Dyad artinya berpasangan dua-dua orang, sedangkan triad artinya membuat kelompok tiga-tiga orang. Pada umumnya dyad dan triad sangat berguna karena memberikan kesempatan bagi anggota untuk memiliki kontak yang lebih personal dengan satu sama lain, mengemukakan ide, dan memvariasikan format kelompok. Adapun kegunaan dari dyad dan triad antara lain: a) Berinteraksi dengan 2 atau 3 individu lainnya; b) Mempraktekkan beberapa keterampilan; c) Melakukan aktivitas antara 2 orang agar dapat berinteraksi dalam kondisi tertentu; d) Bermanfaat dalam mengembangkan aktivitas yang dilakukan kelompok; dan e) Mempererat interaksi yang terjadi antar anggota kelompok.

Contoh Latihan Dyad: Aku harus...Aku memilih...anggota kelompok diminta mengatakan dengan lantang daftar hal-hal yang mereka rasa 'harus' mereka lakukan. Kemudian mereka harus mengubah kata 'saya harus...' menjadi 'saya memilih...' Jenis latihan semacam ini memberi anggota kelompok kesempatan untuk mendengar bagaimana mereka dapat merubah beberapa kebutuhan atau tuntutan mereka. Misalnya: "Saya harus pergi ke kantor tiap pagi."
Diubah menjadi "Saya memilih untuk pergi ke kantor setiap hari." Kemudian tanyakan bagaimana perasaan mereka tentang beban untuk pergi ke kantor setiap hari menjadi lebih ringan. Atau contoh Latihan Triad tentang obrolan orang tua, mintalah anggota kelompok untuk membentuk triad-triad. Masingmasing anggota dalam triad memerankan ayah, ibu dan anak. Kemudian mereka diminta untuk membicarakan suatu masalah dari sudut pandang orangtua dan anak. Setiap anggota harus memerankan ketiga peran tersebut. Latihan ini dapat membantu anggota untuk mempercayai opini orang tua terhadap mereka dan latihan ini dapat dilakukan oleh semua usia.

\section{Creative Props}

Creative crops artinya kreatif menganalogikan perasaan diri. Latihan ini menggunakan berbagai macam peralatan secara kreatif. Peralatan konseling yang berbeda dapat digunakan dalam latihan kelompok yang menarik dan memikat (Jacobs, 1992). Misalnya latihan menggunakan gelas Styrofoam, konselor mengatakan: "Saya ingin setiap orang melihat gelas yang sedang saya pegang, dan anggaplah gelas ini sebagai makna diri kalian masing-masing. (konselor naik ke atas kursi). Saat saya meremas gelas ini saya ingin kalian memikirkan pada siapa kalian akan memberikan makna atas diri kalian, seseorang yang naik ke atas kursi dan kalian izinkan untuk meremas atau menyakiti hati kalian."

Latihan ini dapat melatih imajinasi dan batas toleransi peserta terhadap orang lain yang menyakiti mereka. Contoh lain adalah latihan menggunakan kursi kecil. Konselor berkata: "Kita telah membahas tentang rencana untuk bersenang-senang. Karena itu saya ingin kalian memfokuskan seluruh gagasan pada acara bersenang-senang. Untuk membantu kalian, saya ingin 
kalian melihat kursi kecil ini dan memikirkan tentang anak kecil yang ada dalam dirimu. Saya ingin kalian berpikir tentang apa yang terjadi pada anak itu saat kau tumbuh dewasa. Jika banyak di antara kalian yang merasa kesenangan kalian hilang, saya ingin mendengarnya langsung dari anak kecil yang menjadi bagian dari diri kalian tersebut." Permainan ini dapat merangsang daya khayal peserta dan membuat peserta menghargai kesenangan yang sekarang mereka dapatkan. Peserta juga dapat mengenang masa kanak-kanak mereka yang indah dan sejak kapan kenangan indah tersebut menghilang.

\section{Seni dan Kerajinan Tangan}

Seni dan kerajinan tangan merupakan latihan yang mengharuskan peserta untuk menggambar, memotong, menempel, mengecat, dan mewarnai dengan tujuan untuk menciptakan sesuatu dari berbagai bahan. Seperti latihan lainnya, latihan ini dapat mendatangkan kesenangan, memunculkan minat, mengangkat fokus kelompok, menciptakan energi, dan mengembangkan diskusi. Latihan ini membiarkan peserta mengekspresikan diri dalam berbagai cara yang berbeda.

Misalnya latihan verbal Origami, caranya berikan tiap kelompok sehelai kertas origami. Pilih satu orang untuk maju ke depan ruangan dan menjelaskan kepada orang lain cara melipat kertas menjadi sebuah benda, hewan, atau pesawat kertas. Orang yang memberi petunjuk tersebut mendapatkan petunjuk yang diberikan dari buku atau sumber tertulis lainnya. Penjelasannya harus murni verbal, tidak ada demonstrasi fisik yang dibolehkan. Si pemberi petunjuk juga tidak boleh memberitahu yang lain benda apa yang sedang mereka buat, tapi ia boleh menggambarkannya. Latihan ini merupakan tugas yang sulit jika banyak petunjuk dalam buku berupa diagram.
Permainan ini dapat digunakan terhadap berbagai tingkatan kelompok.

\section{Fantasi}

Latihan fantasi adalah latihan yang paling sering digunakan untuk pengembangan dan terapi kelompok, memberdayakan imajinasi dan penggambaran visual anggota kelompok. Fantasi membantu anggota agar menjadi lebih sadar akan perasaan, harapan, keraguan dan ketakutan mereka. Misalnya latihan "Saya adalah pohon" Cara melakukannya adalah pertama konselor mengatakan: "Saya ingin masing-masing dari kalian menutup mata dan buatlah diri kalian senyaman mungkin. Baiklah, sekarang saya ingin kalian semua membayangkan diri kalian sebagai sebatang pohon. (berhenti sejenak). Pohon apakah kalian? Ada apa saja disekelilingmu? Apakah kehidupan kalian seperti pohon? Bagaimana perasaan kalian saat menjadi pohon? Ok, siapa di antara kalian yang mau maju dan berbagi tentang apa yang telah kalian alami tadi."

\section{Bacaan Umum}

Latihan bacaan umum mensyaratkan peserta untuk membaca cerita pendek, puisi atau dongeng. Bacaanbacaan semacam itu seringkali menyajikan tujuan dari pengembangan ide dan pemikiran serta memperdalam fokus terhadap beberapa topik atau isu. Faktor penting yang harus dipikirkan dalam melakukan latihan bacaan umum ini adalah tujuan kelompok. Pastikan bahwa bahan bacaan akan dapat mengembangkan pemikiran-pemikiran yang berkenaan dengan tujuan tersebut. Pertimbangan lainnya adalah kapabilitas intelektual anggota saat kita meminta mereka untuk membaca dan menanggapi puisi ataupun saat kita meminta mereka menulis sajak. Misalnya latihan" Pembacaan sajak", dalam sebuah kelompok konselor mencoba untuk mengem- 
bangkan diskusi tentang tuntutan dan pengharapan terhadap peserta lain, begitu pula kebutuhan peserta akan pengakuan dan penerimaan. Caranya, Konselor mengatakan: "Saya akan membacakan sebuah sajak dan saya ingin kalian memberikan komentar tentang sajak tersebut. Sajaknya adalah sebagai berikut: Aku melakukan hal yang harus kulakukan begitu pula dengan kau. Aku berada di dunia ini bukan untuk hidup sesuai pengaharapanmu, begitu pula kau. Kau adalah kau dan aku adalah aku. Dan jika ada kesempatan untuk kita saling bertemu : itu adalah hal yang indah Jika tidak, itu tidak akan terbantu.

\section{Umpan Balik}

Latihan umpan balik memungkinkan peserta dan konselor berbagi perasaan dan pemikiran mereka tentang satu sama lain. Konselor tidak seharusnya menggunakan latihan umpan balik kecuali ia merasa bahwa anggota kelompok memiliki keinginan yang cukup untuk saling membantu bukannya keinginan untuk saling menyakiti satu sama lain. Macam-macam latihan umpan balik a) Kesan pertama; b) Daftar cek sifat; c) membicarakan anggota lain; d) Bombardemen kelebihan; e) harapan; dan f) umpan balik tertulis. Contoh, latihan bombardemen kelebihan, caranya konselor: "Saya ingin kalian duduk melingkar dan menyiapkan alat tulis beserta kertasnya. Kemudian saya akan meminta salah seorang peserta untuk duduk di tengah lingkaran, dan peserta lainnya duduk di sepanjang tepi lingkaran. Mereka yang berada di tepi lingkaran bertugas untuk menuliskan berbagai kelebihan yang dimiliki oleh peserta yang berada di tengah lingkaran. Setelah itu kalian boleh bergantian duduk di tengah lingkaran.

Latihan ini memungkinkan peserta untuk berbagi pemikiran dan perasaan terhadap peserta lain dengan cara yang aman dan sedikit kemungkinan untuk menyakiti perasaan orang lain. Contoh lain, Harapan, konselor mengatur latihan ini dengan cara meminta peserta untuk mengungkapkan secara verbal harapanharapan yang mereka punya untuk salah seorang peserta. Ini merupakan latihan yang baik bagi peserta yang peduli terhadap satu sama lain, dan yang memiliki berbagai hal untuk dikatakan kepada peserta lainnya. Konselor: "Saya ingin kalian memikirkan tentang harapan-harapan yang kalian miliki terhadap para anggota lainnya. Kita akan memfokuskan latihan pada satu orang dan pada satu waktu. Siapa saja yang ingin mengemukakan harapannya akan berkata 'Harapan saya untukmu adalah...

\section{Kepercayaan}

Latihan ini dilakukan jika konselor mengetahui atau merasa bahwa peserta tidak saling mempercayai terhadap satu sama lain atau nampaknya kepercayaan lebih dibutuhkan dalam kelompok, ia dapat menggunakan latihan kepercayaan. Setiap latihan bertujuan untuk memfokuskan perhatian kelompok terhadap isu-isu mengenai rasa percaya khususnya untuk mempercayai orang lain. Contoh latihan, secara berpasangan, di mana satu orang ditutup matanya dan yang lain berperan sebagai pemandu. Selama latihan berlangsung tidak ada percakapan apapun kecuali pengarahan. Tujuan dari latihan ini adalah agar peserta dapat mempercayai orang lain untuk memandunya. Setiap peserta harus dipandu berkeliling selama sekitar 5 menit untuk mendapatkan efeknya. Karena itu, ide bagus untuk membawa peserta berjalan melalui pintu-pintu, meja, kursi, tangga dan benda-benda di sekelilingnya.

\section{Dilemma Moral}

Beberapa latihan kelompok dapat digolongkan sebagai "dilemma moral", yakni latihan dimana sebuah cerita dibacakan untuk peserta dan tiap orang harus memutuskan bagaimana ia akan 
menangani situasi dalam cerita itu. Jenis latihan ini berguna dalam membantu anggota kelompok menyadari bahwa setiap orang memiliki nilai-nilai yang berbeda. Latihan ini biasanya memunculkan diskusi tentang nilai-nilai, hukum dan keadilan. Dapat digunakan pada awal sesi dan menjadi fokus dari seluruh sesi. Contoh Latihan: "Kapal karam" Untuk mengembangkan latihan dilemma moral, konselor dapat membacakan cerita pada awal sesi yang nantinya akan menjadi fokus bagi keseluruhan sesi. Salah satu cerita yang bisa dibacakan berjudul, kapal karam. "Kau berada dalam kapal saat kapal tersebut mengalami benturan dan akan tenggelam. Tujuh orang ingin naik ke atas rakit penyelamat, namun rakit tersebut hanya dapat menampung lima orang saja. Ketujuh orang tersebut adalah, kau, anak kecil bandel berusia 12 tahun, pensiunan guru berusia 69 tahun, atlit baseball terkenal berusia 35 tahun, ahli mesin berusia 22 tahun, pendeta berusia 52 tahun, dan seorang wanita hamil berusia 39 tahun. Menurutmu, siapa di antara mereka yang tidak boleh naik rakit?"

\section{Keputusan kelompok}

Latihan ini artinya latihan membuat suatu keputusan. Jenis latihan lainnya yang dapat digunakan dalam kelompok adalah aktivitas pembuatan keputusan kelompok. Latihan ini mensyaratkan para anggota kelompok untuk bekerja sama dalam menangani suatu masalah. Bergantung pada ukuran kelompok, seluruh anggota kelompok bisa saja bekerja sebagai satu unit, atau bisa juga dibagi menjadi dua atau tiga kelompok kecil beranggotakan masingmasing empat orang. Jenis-Jenis Latihan Keputusan Kelompok Johnson dan Johnson (1991) menjelaskan tentang beberapa jenis latihan keputusan kelompok. Dua di antaranya adalah, (1) mengajak peserta untuk berusaha menentukan persediaan apa yang harus diambil (winter survival/bertahan di musim dingin) dan (2) mengajak peserta untuk melengkapi puzzle yang rumit dengan cara bekerjasama (hollow squares exercise).

Contoh Latihan Keputusan Kelompok Winter survival, adalah konselor: "Untuk latihan kali ini saya ingin kalian memecah kelompok menjadi beberapa kelompok kecil masingmasing beranggotakan 3-4 orang. Kalian akan diberikan kertas yang berisi daftar 50 nama benda. Bayangkan diri kalian sebagai pengembara yang akan pergi ke kutub Utara. Kalian hanya diperbolehkan mengambil 15 barang dari daftar tersebut sebagai perbekalan. Diskusikan dalam kelompok kecil kalian, benda apa saja yang akan dibawa dalam perjalanan menuju kutub utara dan siapa yang ditunjuk untuk menjadi pemimpin kalian selama perjalanan, waktunya 15 menit dimulai dari sekarang." Latihan ini dapat melatih peserta dalam proses decision making pengambilan keputusan juga dapat mengasah keterampilan peserta dalam menetapkan skala prioritas dan mengembangkan kekompakkan kelompok.

Pengorganisasian kegiatan bimbingan kelompok dapat dilakukan dengan menggunakan Metode Socratic (Socratic Method). Metode ini terdiri atas empat langkah kegiatan yaitu: a) Eksperientasi (Experience); b) Identifikasi (Identify); c)Analisis (Analize); dan d) Generalisasi (Generalize). a. Fase Eksperientasi (experience) atau disebut juga fase action adalah fase di mana konselor melaksanakan kegiatan konseling (do) yang diarahkan pada upaya memfasilitasi individu untuk mengekspresikan perasaan-perasaan yang menjadi beban psikologisnya sesuai dengan skenario yang telah ditetapkan sebelumnya. $b$. Fase Identifikasi (identify) adalah fase di mana konselor melaksanakan proses identifikasi dan 
refleksi pengalaman selama proses latihan. Pada fase ini konseli atau anggota kelompok diminta untuk bercermin atau melihat (look) ke dalam dirinya apa kaitan antara proses permainan dengan keadaan dirinya. Pada tahap ini konseli diajak untuk mengungkapkan pikiran, perasaan yang terkait dengan proses eksperientasi. Pikiran dan perasaan yang diungkapkan oleh konseli merepresentasikan kondisi psikologis dan permasalahan yang dihadapinya. $c$. Fase analisis (analyze) adalah fase di mana konseli diajak untuk merefleksikan (reflection) dan memikirkan (think) kait- an antara proses konseling dengan kondisi psikologis yang sedang dihadapinya. Sehingga dapat digunakan untuk membuat rencana perbaikan terhadap kelemahan-kelemahan diri. $d$. Fase generalisasi (generalitation) adalah fase di mana konseli diajak untuk membuat rencana (plan) perbaikan terhadap kelemahan yang dihadapi oleh konseli. Rencana perbaikan dapat diwujudkan pada proses konseling berikutnya.

Ringkasan keempat langkah pelaksanaan permainan kelompok dengan menggunakan Socratic Method disajikan melalui gambar berikut.

\begin{tabular}{|l|l|l|l|}
\hline Eksperince----- $\rightarrow$ & Action---- $\rightarrow$ & Do $----\rightarrow$ & "?!\#”^\#@!"” \\
\hline $\begin{array}{l}\text { Identity--------- } \\
\rightarrow\end{array}$ & Reflectio-- $\rightarrow$ & Look-- $\rightarrow$ & What Happened? \\
\hline Analyze--------- $\rightarrow$ & Reflection- $\rightarrow$ & Think-- $\rightarrow$ & So what? \\
\hline Generalize---- $\rightarrow$ & Reflection- $\rightarrow$ & Plan-- $\rightarrow$ & Now what? \\
\hline
\end{tabular}

Skema Pengorganisasian Bimbingan Kelompok menurut Bowers dan Hatct

\section{PENUTUP}

1. Bimbingan kelompok merupakan proses pemberian bantuan kepada individu melalui suasana kelompok yang memungkinkan setiap anggota untuk belajar berpartisipasi aktif dan berbagi pengalaman dalam upaya pengembangan wawasan, sikap dan keterampilan yang diperlukan dalam rangka mengantisipasi timbulnya masalah dan untuk pengembangan pribadi.

2. Pendidikan karakter adalah suatu sistem penanaman nilai-nilai karakter kepada peserta didik yang meliputi komponen pengetahuan, perasaan, ke-

\section{DAFTAR RUJUKAN}

Arismantoro. 2008. Tinjauan Berbagai Aspek Character Building: Bagaimana Mendidik Anak Berkarakter. Edisi I. Yogyakarta: Tiara Wacana sadaran atau kemauan, dan tindakan untuk melaksanakan nilai-nilai tersebut, baik terhadap Tuhan Yang Maha Esa, diri sendiri, sesama, lingkungan, maupun kebangsaan sehingga menjadi manusia sempurna secara umum, dan secara khusus menjadi manusia Indonesia seutuhnya.

3. Latihan permainan merupakan salah satu teknik bimbingan kelompok yang menekankan pada latihan-latihan, aktifitas-aktifitas yang terstruktur, terencana, dan terukur, yang dilakukan oleh anggota kelompok dipimpin oleh konselor.

Arsyad, Azhara. 2012. Strategi dan Implemnetasi Pendidikan karakter Bangsa.

(online).Tersedia:http://azharaarsy $\underline{\text { ad.uin- }}$ 
alaudin.ac.id/index/php?hal $=3 \& \mathrm{~m}$ odel=full=223 (16 Februari 2013)

Bowers dan Hatct. 1998. The National Model for School Counseling Program. Counseling Journal of Amerika. 1998: Vol.3: 69

Direktorat Ketenagaan Kementerian Pendidikan Nasional. 2010. Kerangka Acuan Pendidikan Karakter Tahun Anggaran 2010, (online). Tersedia:

http://www.puskurbuk.net Februari 2012)

Jacobs, Harvill dan Masson. 1994. Group Counseling: Strategies \& Skill. New Jessy: Brooks/Cole Publishing Company

Kementerian Pendidikan Nasional. Undang-undang Republik Indonesia No.20 Tahun 2003 tentang Sistem Pendidikan Nasional.Bandung: Citra Umbara

Megawangi, Ratna. 2004. Pendidikan Karakter Solusi yang Tepat untuk
Membangun Bangsa. Jakarta: Star Energi

Muslich, Masnur. 2011. Pendidikan Karakter Menjawab Tantangan Krisis Multidimensional. Jakarta: Bumi Aksara

Prayitno. 2004. Seri Layanan Bimbingan Kelompok (L.6 dan 7. Padang: UNP Press

Rusmana. 2009. Bimbingan dan Konseling Kelompok di Sekolah (Metode, Teknik dan Apalikasi). Bandung: Rizki Press

Sudrajat, Akhmad. 2010. Pendidikan Karakater di SMP, (online). Tersedia:

http://akhmadsudrajad.wordpress.c om/2010/pendidikan-karakterdismp/. (20 Februari 2012)

Ulwaan, Nasih Abdullah. 1992. Tarbiyatul Awlaad fi al-Islaam. Jeddah: Darussalam 